Review

\title{
Species-specific Fungal DNA in Airborne Dust as Surrogate for Occupational Mycotoxin Exposure?
}

\author{
Anne Straumfors Halstensen \\ National Institute of Occupational Health, Department of Chemical and Biological Working \\ Environment, Gydasvei 8, Pb. 8149 Dep., N-0033 Oslo, Norway \\ E-Mail: anne.s.halstensen@stami.no; Tel. +47-23-19-53-38; Fax: +47-23-19-52-06
}

Received: 7 November 2008; in revised form; 8 December 2008 / Accepted: 10 December 2008 / Published: 10 December 2008

\begin{abstract}
Possible health risks associated with occupational inhalation of mycotoxincontaining dust remain largely unknown, partly because methods for mycotoxin detection are not sensitive enough for the small dust masses obtained by personal sampling, which is needed for inhalable exposure measurements. Specific and sensitive PCR detection of fungi with mycotoxin-producing potential seem to be a good surrogate for occupational exposure measurements that include all fungal structures independent of morphology and cultivability. Results should, however, be interpreted with caution due to variable correlations with mycotoxin concentrations.
\end{abstract}

Keywords: Occupational exposure; mycotoxin exposure; inhalation; PCR; fungi.

\section{Introduction}

Mycotoxins are fungal metabolites that may exert immunosuppressive, endocrine, carcinogenic and toxic effects on human and animals. Several mycotoxins are natural contaminants of grain and other agricultural products. The increasing focus on mycotoxins, particularly in the grain production industry, along with unavoidable dust exposure during crop handling, have led to a growing concern about the inhalable contribution of mycotoxin exposure in occupational settings.

The major mycotoxin classes of concern are trichothecenes, aflatoxins, fumonisins, zearalenone, and ochratoxin A, which are produced by the three fungal genera Fusarium, Aspergillus and Penicillium [1]. The trichothecenes comprise a large class of mycotoxins produced by several fungal 
genera, notably Fusarium species. Some of the most commonly occurring trichothecenes in grain are deoxynivalenol (DON), T-2 toxin, HT-2 toxin, nivalenol (NIV), diacetoxyscirpenol (DAS), and monoacetoxyscirpenol (MAS). Aflatoxins are primarily produced by Aspergillus flavus and Aspergillus paraciticus; fumonisins (FUM) are produced by Fusarium verticollioides and occur primarily in corn; zearalenone (ZEA) is produced primarily by Fusarium graminearum; and ochratoxin A (OTA) is primarily produced by Penicillium verrucosum and Aspergillus ochraceus. The dominant fungal species and the mycotoxins they produce may vary from one part of the world to another, depending on differences in climate and topography. At the local level, there is a high degree of mycotoxin concentration variability in crops and dust, as with their fungal producers [2-5].

The health risk from ingesting mycotoxin-contaminated agricultural products is widely acknowledged and to a certain extent controlled, but little is known whether inhalation of mycotoxincontaining dust during crop handling represents an occupational health risk. Inhaled trichothecene mycotoxins are very toxic [6-9], and may be even more toxic than dermally, orally and intraperitoneally administered mycotoxins [6,9-10], presumably due to higher bioavailability [10-11]. Epidemiological studies have, furthermore, implicated that adverse human health effects are caused by inhalation of mycotoxins [12-14]. However, the intensity and duration of mycotoxin inhalation that cause health effects is unknown since no human effects studies of inhaled mycotoxins exist. Presently, one can therefore not determine whether adverse mycotoxin levels can be reached during different working conditions where mycotoxin-contaminated dusts are inhaled.

A proper exposure assessment is needed when evaluating health effects of work place exposure. This requires personal sampling [15] and quantitative determination of the agents of interest. The personal dust sampling equipment typically consists of a portable pump that aspirates air from the breathing zone through a sampling cassette which collects airborne dust on a filter. The sampling equipment is carried by the worker during work in order to sample dust that is representative for the workers exposure.

Mycotoxin measurements in the small dust masses obtained by personal sampling has not yet been reported, although this may in theory be possible with the low detection limits of several recent methods [5, 16-17]. Because it is easier to detect, fungi are often used as an indirect measure for mycotoxins both in agricultural and occupational settings. However, one needs to quantify and identify the fungi at the species level because the mycotoxin production depends on fungal genus, species and strain [18]. Traditional methods for fungal determination, such as microscopy and cultivation, do either not discriminate closely related species or are limited to cultivable fungi. Molecular techniques such as polymerase chain reaction (PCR) and DNA hybridization have provided significant advances in rapid identification and quantification of specific fungal DNA, irrespective of their cultivability. PCR-based detection of species-specific fungal DNA has recently been used to measure personal exposure of toxigenic Fusarium species [19].

This review focuses on the use of species-specific PCR to detect toxigenic fungi in personal air samples, and how this may be used to evaluate occupational mycotoxin exposure. Trichothecenes and toxigenic Fusaria in grain and grain dust are given special attention. The new approach prompts a thorough discussion of how to interpret the results compared to cultivation ( $\mathrm{cfu} / \mathrm{m}^{3}$ ) and microscopy $\left(\right.$ spores $\left./ \mathrm{m}^{3}\right)$. 


\section{Personal mycotoxin exposure measurements in occupational environments}

Although median dust exposure in e.g. grain handling may be $5 \mathrm{mg} / \mathrm{m}^{3}$ dust [20], less than $1 \mathrm{mg}$ is often collected on the filter. Analytical mycotoxin detection methods have primarily been developed to analyze food products, and are thus not optimized for the small dust masses obtained by personal sampling. This may partly explain why only few have studied occupational mycotoxin exposure [21-23].

Stationary sampling with high volume pumps is an alternative that has been used to determine airborne mycotoxin level [21-22, 24]. Other studies have used settled dust which can be obtained in larger quantities, and related the mycotoxin concentration per gram of settled dust to the level of airborne dust $[5,25]$. Theoretically, grain handlers may inhale up to $34 \mu \mathrm{g}$ mycotoxin during a workday [26].

\section{Surrogates for mycotoxin measurements}

Fungi are often used as indicators for mycotoxins both in agricultural and occupational settings, but they must be quantified and identified at the species level in order to relate the fungi to a certain mycotoxin because the mycotoxin production depends on both the fungal genus, species and strain [18]. Airborne fungi collected by impaction or filtration have primarily been identified by cultivation which limits the methods to cultivable fungi. Microscopic counting of total fungi quantifies both cultivable and non-cultivable spores, but has limited potential for identification [27-31].

\subsection{Cultivation of fungi}

Cultivable fungi may grow on semi-solid nutrient media to form colonies that can be counted with the unaided eye. Since a colony can be derived from one single microorganism or from an aggregate, the microbial exposure is expressed as colony forming units $(\mathrm{cfu}) / \mathrm{m}^{3}$. Fungal colonies can be classified by their morphological appearance and eventually identified by their characteristics in culture, smell and light microscopic morphology [30]. However, rapidly growing fungi often out-compete and inhibit slowly growing species, resulting in a bias towards rapidly growing fungi [32-33]. Furthermore, various microbial species may demand different growth conditions, making optimization for each species an extensive task. Finally, colony counting may grossly underestimate the total number of microorganisms in airborne dust samples because aggregates of several individual propagules will be counted as one colony.

\subsection{Microscopic methods}

Fungi collected on filters may be directly counted in a light microscope provided they have a recognizable morphology, which unfortunately is often not the case with aerosolized microorganisms. High diversity, intra-species variability, and conflicting taxonomy of some genera, such as the Fusarium genus, add to this complexity. Staining of different fungal components with various fluorochromes followed by epifluorescence microscopy may facilitate microorganism recognition, 
although less detailed than with light microscopy [34-35]. This method is further limited by the fact that fungal spores of some species may resist staining or mask the fluorescence by dark pigmentation [36] and fungi appearing in large aggregates may lead to counting errors [34].

Scanning electron microscopy (SEM) provides a greater resolution and field depth than light and fluorescence microscopy, and allows a certain morphological recognition and classification of fungal spores and actinomycetes [37], but species identification is generally not possible. Airborne spores are subject to desiccation that may make some species, such as Fusarium, hard to recognize.

Although non-culture based methods may provide more valid exposure estimates than culture-based methods, their validity also depend on the ability to differentiate between species. This may be particularly important when examining fungal exposure in diseases such as allergic asthma, allergic rhinitis and hypersensitivity pneumonitis, but perhaps less obvious for "non-specific" diseases such as airway inflammation, non-allergic asthma, bronchitis and inhalation fever.

\subsection{DNA-based fungal analysis}

\subsubsection{Important fungal genomic DNA regions}

Molecular techniques such as PCR and DNA hybridization have provided significant advances in rapid detection and characterization of specific fungal DNA, irrespective of their viability or cultivability. To utilize the technique for identification is knowledge of the fungal DNA sequence essential.

Fungal ribosomal DNA (rDNA) contains both conserved nucleotide sequences that are common to all fungi, and variable sequences that are suitable for species discrimination. The conserved fungal rRNA genes are separated by two variable internal transcribed spacer regions (ITS1 and ITS2) and organized in a tandemly repeated unit. Adjacent copies of the rDNA repeat unit are separated by an even higher variable intergenic spacer (IGS) region. Both ITS and IGS appear to evolve more rapidly than the rDNA genes, and have been used to study closely related taxa [38-39], whereas the conserved rDNA sequences have been widely used to study distantly related fungi [40].

However, high mutation rates could also cause instability of markers based on ITS and IGS. Several protein-coding genes, such as the elongation factor- 1 alpha and the $\beta$-tubulin genes have therefore been explored as phylogenetic markers $[39,41]$.

Alternative strategies are the utilization of unique sequences in mitochondrial DNA [42] or cloned restriction fragments of genomic DNA [43]. In spite of the high polymorphism in these regions, it is not always sufficient to obtain species-specific primers, particularly when the pathogen under investigation appears together with closely related non-pathogenic species [44].

Sequence characterization of randomly amplified polymorphic DNA (RAPD) fragments reveals more sequence-specific polymorphisms than ITS-sequencing and was for the first time used by Paran and Michelmore to detect resistance genes for mildew in lettuce [45]. This method has successfully been used to discriminate between closely related Fusarium species such as F. graminearum and $F$. culmorum [46], and resulted in primers specific for F. avenaceum [44].

Several group-specific competitive PCR methods have quantified a number of trichotheceneproducing Fusarium species in grain using primers based on sequences from the gene encoding 
trichodiene synthase (tri5), which catalyses the first step in the trichothecene biosynthetic pathway [47-48]. A similar approach was used to detect aflatoxin-producing and sterigmatocystin-producing fungi [49-50], and the IGS region between tri5 and the tri6 gene (encoding a transcription factor) has been used to distinguish between high and low DON-producing F.culmorum isolates [51]. The recently characterized genes encoding various polyketide synthases required for the production of ZEA in $F$. graminearum [52-53], and OTA in P. verrucosum and P. nordicum [54], may also be used to detect fungi with specific mycotoxin-producing potential.

\subsubsection{Real-time PCR of toxigenic fungi in bioaerosol samples}

Several PCR-based techniques may be suitable for air samples with low spore density [55-57]. However, quantitative real-time PCR using amplicon sequence non-specific fluorescent dyes [58-59] or sequence-specific fluorescent probes [60-62] is at present probably the best method for detection of airborne fungi because of the rapid, sensitive and specific quantification provided by the continuous amplification monitoring and absence of post-PCR electrophoretic needs [63-66]. Furthermore, the use of different fluorescent dyes may facilitate detection of several target microorganisms in a single reaction (multiplex PCR) [61, 66].

Quantitative real-time PCR assays have been developed to either specifically detect one particular mycotoxin-producing species, or several species with the same mycotoxin production-related genes [58, 67-68]. Several airborne fungal groups and species have been quantified by real-time PCR with the TaqMan fluorogenic hybridisation probe system [19, 69-70]. Most of these studies are based on stationary sampling, which may underestimate workers exposure to bioaerosols [71-72]. Only one study on specific fungal DNA quantification in personal samples has been published [19].

\section{Methodological considerations}

PCR has the advantage of specific identification of fungal DNA independent of cultivability, including all DNA-containing fungal structures, such as hyphae which are important contributors to mycotoxin production and bioaerosol exposure [73]. The introduction of molecular methods in occupational hygiene and indoor air has therefore improved the specificity of microbial exposure measurements and allowed rapid identification [59, 70, 74-76].

\subsection{Detection sensitivity}

The sensitivity of the PCR method is dependent on the primer sequences, and the detection sensitivity may vary 100-1000 fold for various Fusarium species [77]. Primers from the multiple-copy ITS sequences, may increase the sensitivity compared to primers from RAPD fragments or single copy genes such as tri5. A nested PCR will also increase the sensitivity compared to standard PCR [78]. Other ways to increase both the detection sensitivity and specificity is PCR followed by probe hybridization [56-57].

Detection sensitivity can be tested either by extracting DNA from a large amount of spores followed by DNA dilution or starting with a spore suspension dilution followed by DNA extraction. 
The first procedure gives higher detection sensitivity due to high extraction efficiency from high spore density. For samples with low spore density, which is the case for most personal air samples, the DNA extraction efficiency and recovery may be lower, and result in larger variation in detection sensitivity [56].

\subsection{PCR inhibitors}

Environmental PCR inhibiting contaminants may be co-extracted with DNA. Samples from different environments may vary in chemical and organic composition, and affect assay sensitivity differentially. Environmental compounds like phenols, humic and fulvic acids in soil, polyphosphates in fungi, heavy metals, some plant acidic polysaccharides, and high concentrations of non-target DNA may inhibit polymerase activity, thus causing false-negative results and reduced detection sensitivity [79-81]. However, PCR inhibitors may be removed by including a purification step in the extraction procedure $[19,77,82]$.

Possible inhibition may be tested either by spiking the processed sample with known amount of target DNA, or spiking the unprocessed sample with known amounts of target spores. Spiking the processed sample is easiest, but it will not correct for the DNA isolation efficiency [70]. The second approach examines both the DNA isolation efficiency and the existence of any PCR inhibition substances so that the standard curve and the tested sample can be compared. However, the number of available parallel samples to be spiked for the standard curve may be limited, although the optimal solution is to spike all samples. Moreover, the standard line constructed in this procedure may not be linear due to different DNA isolation efficiency at different spore concentrations. Differences in DNA extraction efficiency may also be expected between various fungal species and between spores and hyphae. The extraction variability of common species should therefore be determined in order to standardize the extraction procedure so that all fungi in a complex sample may have similar extraction efficiencies. However, the variable microbial content in work place samples may have differential influence on the extraction efficiency and may be an unavoidable source of uncertainty associated with DNA extraction. Furthermore, spiking with target DNA may not discriminate between inhibition and no detectable target. Spiking with unrelated DNA that is not expected to be found in the samples may be more reliable as a positive internal control [68].

DNA extract dilution is known to attenuate the inhibition effect, but also to reduce the sensitivity $[63,83]$. Moreover, filters of cellulose and nitrocellulose, but not polycarbonate, may inhibit PCR [84].

\section{Microarrays}

DNA microarray is another powerful tool for the parallel detection of multiple DNA sequences in one single experiment [85]. The fundamental basis for microarray is the ability of complementary DNA sequences to hybridize, but the microarray design varies depending on the research question [8689] and several platforms exists [90].

Although the majority of microarray reports are concerned with gene expression profiling in humans, animals or plants, the use of DNA microarray technology is expanding into new fields and new applications. Several microarrays have been developed for detection of pathogens that pose 
threats to human, animal and plant health [81, 85, 91-92] or for better understanding of the microbial world, with particular emphasis on strain detection, assessment of microbial diversity and the structure of different communities, adaptation, expression of biologically important genes and evolution [90, 9396]. However, microarray has thus far not been used for microbial screening of bioaerosols, which could be relevant in occupational environments.

\section{Measurements in settled versus airborne dust}

Several specific toxigenic Fusarium spp. have been identified and quantified in settled grain dust by species-specific semi-quantitative PCR, whereas they could not be sufficiently identified or quantified by cultivation [77]. F. langsethia- and tri5-specific DNA correlated fairly strong with HT-2 and T-2 $\left(r_{\text {spearman }}=0.77\right.$ and $r_{\text {spearman }}=0.59$, respectively, for $F$. langsethiae and $r_{\text {spearman }}=0.68$ and $r_{\text {spearman }}=0.50$, respectively, for tri5).

Settled dust collected for mycotoxin determination may be used as surrogate for airborne dust under the assumption that settled dust is representative for airborne dust. However, as the aerosolization potential of dust components depend on microbial species, weather, agricultural equipment, and drierand storage technology, this may not always be correct. Spatial variation in airborne dust concentration and faster sedimentation of larger particles than smaller increase the differences further.

Although Fusarium-DNA concentration was higher in settled dust than in airborne dust, airborne Fusarium-DNA was detected in personal samples even after only 10 minutes sampling time [19].

\section{General limitations of mycotoxin surrogates}

As the genes of the trichothecene biosynthetic pathway are not expressed constitutively, but are induced by developmental and environmental signals [97], the detection of potentially toxigenic fungal species may not in general predict mycotoxin presence. Presence of non-mycotoxin-producing fungi may lead to an overestimation of the predicted mycotoxin concentration. On the other hand, as the mycotoxins may be present long after the death and disintegration of the producer, an underestimation of the mycotoxin concentration is also possible. Although DNA specific for tri5, F. langsethiae and F. poae have been shown to correlate strongly with HT-2 and T-2 in an epidemiological study, not all expected associations were present [77]. This common problem is a limitation of the use of possible toxin-producers as indicators for toxins. Only few studies have analyzed the correlation between PCR signals and certain mycotoxin levels, and even fewer have reported positive correlations [98].

\section{Evaluation and interpretations of data from molecular analysis}

The data output from the molecular techniques are either PCR gel band intensity values or cycle threshold $\left(\mathrm{C}_{\mathrm{T}}\right)$ values from the real time PCR machine. The latter reflects PCR cycle number when the specific signal is detected above a certain threshold value. Although the original amount of specific DNA may be calculated for both outputs when using a known standard DNA concentration, real time PCR is more accurate. Information of DNA concentrations may be sufficient as surrogates for mycotoxins where correlations between fungi and mycotoxin have been established, but for 
bioaersosol exposure assessment in general, the DNA concentration should preferably be converted to a form that is applicable to occupational measures. The average ascomycetous fungal genome size is $36 \mathrm{Mb}$, corresponding to $40 \mathrm{fg}$ genomic DNA. The number of cells (spores) per cubic meters of air (cells $/ \mathrm{m}^{3}$ or spore equivalents $/ \mathrm{m}^{3}$ ) has been calculated by conversion of $40 \mathrm{fg}$ DNA per fungal cell (spore) [59]. Others have estimated the number of conidia detected in dust samples by using an equation that expresses the relationship between the differences in real time PCR $\mathrm{C}_{\mathrm{T}}$ values between the test assay and a reference assay with known conidia number $\left(\Delta \mathrm{C}_{\mathrm{T}}\right)$ and the number of target cell equivalents [75]. In another study, the Fusarium-DNA exposure was converted to number of genomes per cubic meters of air (genomes $/ \mathrm{m}^{3}$ ) by using the known haploid genome size of F. graminearum [99] and the sampled air volume [19].

When choosing exposure denomination it is important to evaluate what is quantified and what is relevant to occupational health. Fungi have many and various forms that may have variable number nuclei. The term spore equivalents may be misleading if the spores have multiple nuclei. However, the aerosolized unit, single or aggregated spores and hyphal fragments, may be most relevant for inhalation. Since the quantification of DNA includes both spores and hyphae, the DNA- based exposure results will be higher than both cultivation- or microscopy-based results.

\section{OEL for fungi?}

Several countries have adopted 8-hour time weighted average occupational exposure limits (OELs) for organic dust at $5 \mathrm{mg} / \mathrm{m}^{3}$ [100] and for grain dust of $4 \mathrm{mg} / \mathrm{m}^{3}$ [101]. A major problem of using this permissive dust level for evaluation of work-related health risks is that organic dusts consist of a complex mixture of diverse biologically active components which may have additive or synergistic effects. Nevertheless, for fungal spores the combined evidence from human challenge and epidemiological studies support fairly consistent lowest observed respiratory effects levels of approximately $10^{5}$ spores $/ \mathrm{m}^{3}$ for diverse fungal species in non-sensitized populations [102]. However, toxigenic fungi are likely to have much lower effect levels, and may also cause other health effects than non-mycotoxin-producing fungi. Species identification, e.g. by PCR, is therefore needed before one can evaluate such data. To confirm exposure, mycotoxins or mycotoxin metabolites may be detected in biological samples [103-105]. Furthermore, biological effect markers of mycotoxin exposure, such as aflatoxin $\mathrm{B}_{1}-\mathrm{N}^{7}$-guanine adducts, are possible to detect. As intermediate outcomes in the process leading to adverse health effects, such markers are important to evaluate in exposureresponse association studies.

\section{Conclusions}

The specificity and sensitivity of the PCR technology makes identification of microorganisms much easier and should therefore be used more in occupational exposure assessments. The detection of DNA sequences related to mycotoxin synthesis indicates presence of fungi with mycotoxin producing potential, and may predict mycotoxin exposure. However, fungal DNA as indicators of trichothecenes presence should be used with caution, as the fungal DNA not necessarily reflects mycotoxins presence. 


\section{Future prospects}

The more we learn about non-infectious microorganisms and their effect on human health, the more important becomes species identification. Since various species have different pathogenic potential, species identification is very relevant to health risk assessments. DNA-based detection of specific microbial species or genes related to their toxicity may lead to improved exposure estimates of known microorganisms, and may subsequently provide the possibility to establish OELs for specific fungi and other microorganisms.

An attractive possibility for the future would be the microbial screening of various occupational environments by the microarray technology. Initially, this could be implemented for research purposes, but it could also be a method to identify characteristic microbial profiles of the various occupational environments that subsequently could ease the control measures by rapid screening.

\section{Acknowledgements}

Professor Trond Sundby Halstensen at the Institute of Oral Biology, University of Oslo and Dr. Wijnand Eduard at the National Institute of Occupational Health are greatly acknowledged for critical reading of the manuscript.

\section{References}

1. Council for Agricultural Science and Technology. Mycotoxins - Risks in plant, animal, and human systems. Task Force Report no. 139. CAST: Iowa, USA, 2003.

2. Krysinska-Traczyk, E.; Kiecana, I.; Perkowski, J.; Dutkiewicz, J. Levels of fungi and mycotoxins in samples of grain and grain dust collected on farms in eastern Poland. Ann. Agric. Environ. Med. 2001, 8, 269-274.

3. Nordby, K.C.; Halstensen, A.S.; Elen, O.; Clasen, P.E.; Langseth, W.; Kristensen, P.; Eduard, W. Trichothecene mycotoxins and their determinants in settled dust related to grain production. Ann. Agric. Environ. Med. 2004, 11, 75-83.

4. Krysinska-Traczyk, E.; Perkowski, J.; Dutkiewicz, J. Levels of fungi and mycotoxins in the samples of grain and grain dust collected from five various cereal crops in eastern Poland. Ann. Agric. Environ. Med. 2007, 14, 159-167.

5. Mayer, S.; Curtui, V.; Usleber, E.; Gareis, M. Airborne mycotoxins in dust from grain elevators. Mycotoxin Res. 2007, 23, 94-100.

6. Creasia, D.A.; Thurman, J.D.; Wannermacher, R.W., Jr.; Bunner, D.L. Acute inhalation toxicity of T-2 mycotoxin in the rat and guinea pig. Fundam. Appl. Toxicol. 1990, 14, 54-59.

7. Pang, V.F.; Lambert, R.J.; Felsburg, P.J.; Beasley, V.R.; Buck, W.B.; Haschek, W.M. Experimental T-2 toxicosis in swine following inhalation exposure: Clinical signs and effects on hematology; serum biochemistry; and immune response. Fund. Appl. Toxicol. 1988, 11, 100-109.

8. Ren, Y.; Zhang, Y.; Shao, S.; Cai, Z.; Feng, L.; Pan, H.; Wang, Z. Simultaneous determination of multicomponent mycotoxin contaminants in foods and feeds by ultra-performance liquid chromatography tandem mass spectrometry. J. Chromatogr. A. 2007, 1143, 48-64. 
9. Schiefer, H.B.; Hancock, D.S. Systemic effects of topical application of T-2 toxin in mice. Toxicol. Appl. Pharmacol. 1984, 74, 464-472.

10. Amuzie, C.J.; Harkema, J.R.; Pestka, J.J. Tissue distribution and proinflammatory cytokine induction by the trichothecene deoxynivalenol in the mouse: comparison of nasal vs. oral exposure. Toxicology 2008, 248, 39-44.

11. Petzinger, E.; Ziegler, K. Ochratoxin A from a toxicological perspective. J. Vet. Pharmacol. Ther. 2000, 23, 91-98.

12. Kristensen, P.; Andersen, A.; Irgens, L.M. Hormone-dependent cancer and adverse reproductive outcomes in Norwegian farmers' families - effect of climatic conditions favouring fungal growth in grain. Scand. J. Work Environ. Health. 2000, 26, 331-337.

13. McLaughlin, J.K.; Malker, H.S.R.; Malker, B.K.; Stone, B.J.; Ericsson, J.L.E.; Blot, W.J.; Weiner, J.A.; Fraumeni, J.F. Registry-based analysis of occupational risks for primary liver cancer in Sweden. Cancer Res. 1987, 47, 287-291.

14. Nordby, K.C.; Andersen, A.; Kristensen, P. Incidence of lip cancer in the male Norwegian agricultural population. Cancer Causes Control. 2004, 15, 619-626.

15. Adopted European Standard CEN 689. Workplace atmosphere - Guidance for the assessment of exposure by the inhalation to chemical agents for comparison with limit values and measurement strategy, European Committee for Standardization: Bruxelles, Belgium, 1995.

16. Brasel, T.L.; Martin, J.M.; Carriker, C.G.; Wilson, S.C.; Straus, D.C. Detection of airborne Stachybotrys chartarum macrocyclic trichothecene mycotoxins in the indoor environment. Appl. Environ. Microbiol. 2005, 71, 7376-7388.

17. Bloom, E.; Bal, K.; Nyman, E.; Must, A.; Larsson, L. Mass spectrometry-based strategy for direct detection and quantification of some mycotoxins produced by Stachybotrys and Aspergillus spp. in indoor environments. Appl. Environ. Microbiol. 2007, 73, 4211-4217.

18. Thrane, U.; Adler, A.; Clasen, P.E.; Galvano, F.; Langseth, W.; Lew, H.; Logrieco, A.; Nielsen, K.F.; Ritieni, A. Diversity in metabolite production by Fusarium langsethiae, Fusarium poae, and Fusarium sporotrichioides. Int. J. Food Microbiol. 2004, 95, 257-266.

19. Halstensen, A.S.; Nordby, K.C.; Eduard, W.; Klemsdal, S.S. Real-time PCR detection of toxigenic Fusarium in airborne and settled grain dust and associations with trichothecene mycotoxins. J. Environ. Monit. 2006, 8, 1235-1241.

20. Melbostad, E.; Eduard, W. Organic dust-related respiratory and eye irritation in Norwegian farmers. Am. J. Ind. Med. 2001, 39, 209-217.

21. Burg, W.R.; Shotwell, O.L.; Saltzman, B.E. Measurements of airborne aflatoxins during the handling of 1979 contaminated corn. Am. Ind. Hyg. Ass. J. 1981, 43, 580-586.

22. Burg, W.R.; Shotwell, O.L.; Saltzman, B.E. Measurements of airborne aflatoxins during the handling of contaminated corn. Am. Ind. Hyg. Ass. J. 1982, 42, 1-11.

23. Selim, M.I.; Juchems, A.M.; Popendorf, W. Assessing airborne aflatoxin B1 during on-farm grain handling. Am. Ind. Hyg. Ass. J. 1998, 59, 252-256.

24. Lappalainen, S.; Nikulin, M.; Berg, S.; Parikka, P.; Hintikka, E.L.; Pasanen, A.L. Fusarium toxins and fungi associated with handling of grain on eight Finnish farms. Atm. Environ. 1996, 30, 3059-3065. 
25. Halstensen, A.S.; Nordby, K.C.; Elen, O.; Eduard, W. Ochratoxin A in grain dust - Estimated exposure and relations to agricultural practices in grain production. Ann. Agric. Environ. Med. 2004, 11, 245-254.

26. Halstensen, A.S.; Nordby, K.C.; Kristensen, P.; Eduard, W. Mycotoxins in grain dust [review] Stewart Postharvest Review. 2008, 4, 9:1-9:9. Online ISSN: 1745 - 9656.

27. Blomquist, G.; Palmgren, U.; Ström, G. Improved techniques for sampling airborne fungal particles in highly contaminated environments. Scand. J. Work Environ Health. 1984, 10, 253-255.

28. Crook, B.; Sherwood-Higham, J.L. Sampling and assay of bioaerosols in the work environment. J. Aerosol Sci. 1997, 28, 417-426.

29. Dutkiewicz, J.; Pomorski, Z.J.H.; Sitkowska, J.; Krysinska-Traczyk, E.; Skorska, C.; Prazmo, Z.; Cholewa, G.; Wojtowicz, H. Airborne microorganisms and endotoxin in animal houses. Grana. 1994, 33, 85-90.

30. Eduard, W.; Heederik, D. Methods for quantitative assessment of airborne levels of non-infectious microorganisms in highly contaminated work environments. Am. Ind. Hyg. Ass. J. 1998, 59, 113-127.

31. Kotimaa, M.H.; Husman, K.H.; Terho, E.O.; Mustonen, M.H. Airborne molds and actinomycetes in the work-environment of farmers' lung patients in Finland. Scand. J. Work Environ. Health. 1984, 10, 115-119.

32. MacNeil, L.; Kauri, T.; Robertson, W. Molecular techniques and their potential application in monitoring the microbiological quality of indoor air. Can. J. Microbiol. 1995, 41, 657-665.

33. Wu, P.C.; Su, H.J.; Ho, H.M. A comparison of sampling media for environmental viable fungi collected in a hospital environment. Environ. Res. 2000, 82, 253-257.

34. Heldal, K.; Skogstad, A.; Eduard, W. Improvements in the quantification of airborne microorganisms in the farm environment by epifluorescence microscopy. Ann. Occup. Hyg. 1996, 40, 437-447.

35. Palmgren, U.; Ström, G.; Blomquist, G.; Malmberg, P. Collection of airborne microorganisms on Nucleopore filters, estimations and analysis - CAMNEA method. J. Appl. Bacteriol. 1986, 61, 401-406.

36. Burge, H.A. Bioaerosol investigation. In Bioaerosols; Burge, H.A., Ed.; CRC Press: Boca Raton, FL, 1995; pp. 1-23.

37. Eduard, W.; Sandven, P.; Johansen, B.; Bruun, R. Identification and quantification of mould spores by scanning electron microscopy (SEM): Analysis of filter samples collected in Norwegian sawmills. Ann. Occup. Hyg. 1988, 32, 447-455.

38. Appel, D.J.; Gordon, T.R. Relationships among pathogenic and non-pathogenic isolates of Fusarium oxysporum based on the partial sequence of the intergenic spacer region of the ribosomal DNA. Mol. Plant. Microbe Interact. 1996, 9, 125-138.

39. Yli-Mattila, T.; Mach, R.L.; Alekhina, I.A.; Bulat, S.A.; Koskinen, S.; Kullnig-Gradinger, C.M.; Kubicek, C.P.; Klemsdal, S.S. Phylogenetic relationship of Fusarium langsethiae to Fusarium poae and Fusarium sporotrichioides as inferred by IGS, ITS, $\beta$-tubulin sequence and UP-PCR hybridization analysis. Int. J. Food Microbiol. 2004, 95, 267-285. 
40. Hillis, D.M.; Dixon, M.T. Ribosomal DNA: Molecular evolution and phylogenetic inference. Quart. Rev. Biol. 1991, 66, 411-453.

41. Knutsen, A.K.; Torp, M.; Holst-Jensen, A. Phylogenetic analyses of the Fusarium poae, Fusarium sporotrichioides and Fusarium langsethiae species complex based on partial sequencees of the translation elongation factor-1 alpha gene. Int. J. Food Microbiol. 2004, 95, 287-295.

42. Schesser, K.; Luder, A.; Henson, J.M. Use of polymerase chain reaction to detect the take-all fungus Gaeumannomyces graminis in infected wheat plants. Appl. Environ. Microbiol. 1991, 57, 553-556.

43. Minsavage, G.V.; Thompson, C.M.; Hopkins, D.L.; Leite, R.M.V.B.C.; Stall, R.E. Development of a polymerase chain reaction protocol for detection of Xylella fastidiosa in plant tissue. Phytopathology 1994, 84, 456-461.

44. Turner, A.S.; Lees, A.K.; Rezanoor, H.N.; Nicholson, P. Refinement of PCR-detection of Fusarium avenaceum and evidence from DNA marker studies for phenetic relatedness to Fusarium tricinctum. Plant Pathol. 1998, 47, 278-288.

45. Paran, I.; Michelmore, R.W. Development of reliable PCR-based markers linked to downy mildew resistance genes in lettuce. Theor. Appl. Genet. 1993, 85, 985-993.

46. Schilling, A.G.; Møller, E.M.; Geiger, H.H. Polymerase Chain Reaction based assays for speciesspecific detection of Fusarium culmorum, F. graminearum and F. avenaceum. Mol. Plant Pathol. 1996, 86, 515-522.

47. Edwards, S.G.; Pirgozliev, S.R.; Hare, M.C.; Jenkinson, P. Quantification of trichotheceneproducing Fusarium species in harvested grain by competitive PCR to determine efficacies of fungicides against fusarium head blight of winter wheat. Appl. Environ. Microbiol. 2001, 67, 1575-1580.

48. Niessen, M.L.; Vogel, R.F. Group specific PCR-detection of potential trichothecene-producing Fusarium-species in pure cultures and cereal samples. Syst. Appl. Microbiol. 1998, 21, 618-621.

49. Geisen, R. Multiplex polymerase chain reaction for the detection of potential aflatoxin and sterigmatocystin producing fungi. Syst. Appl.Microbiol. 1996, 19, 388-392.

50. Shapira, R.; Paster, N.; Eyal, O.; Menasherow, M.; Mett, A.; Salomon, R. Detection of Aflatoxinogenic molds in grains by PCR. Appl. Environ. Microbiol. 1996, 62, 3270-3273.

51. Bakan, B.; Giraud-Deville, C.; Pinson, L.; Richard-Molard, D.; Fournier, E.; Bryggo, Y. Identificationby PCR of Fusarium culmorum strains producing large and small amount of deoxynivalenol. Appl. Environ. Microbiol. 2002, 68, 5472-5479.

52. Gaffoor, I.; Train, F. Characterization of two polyketide synthase genes involved in zearalenone biosynthesis in Gibnerella zeae. Appl. Environ.Microbiol. 2006, 72, 1793-1799.

53. Lysoe, E.; Klemsdal, S.S.; Bone, K.R.; Frandsen, R.N.J.; Johansen, T.; Thrane, U.; Giese, H. The PKS4 gene of Fusarium graminearum is essensial for zearalenone production. Appl. Environ. Microbiol. 2006, 72, 3924-3932.

54. Schmidt-Heydt, M.; Richter, W.; Michulec, M.; Buttinger, G.; Geisen, R. Comprehensive molecular system to study the presence, growth and ochratoxin A biosynthesis of Penicillum verrucosum in wheat. Food Addit. Contamin. 2008, 25, 989-996.

55. Williams, R.H.; Ward, E.; McCartney, H.A. Methods for integrated air sampling and DNA analysis for detection of airborne fungal spores. Appl. Environ. Microbiol. 2001, 67, 2453-2459. 
56. Wu, Z.; Blomquist, G.; Westermark, S.-O.; Wang, X.-R. Application of PCR and probe hybridization techniques in detection of airborne fungal spores in environmental samples. $J$. Environ. Monit. 2002, 4, 673-678.

57. Zeng, Q.Y.; Rasmuson-Lestander, Å.; Wang, X.R. Extensive set of mitochondrial LSU rDNAbased oligonucleotide probes for the detection of common airborne fungi. FEMS Microbiol. Lett. 2004, 237, 79-87.

58. Schnerr, H.; Niessen, L.; Vogel, R.F. Real time detection of the tri5 gene in Fusarium species by lightcycler-PCR using SYBR Green I for continuous fluorescence monitoring. Int. J. Food Microbiol. 2001, 71, 53-61.

59. Zeng, Q.Y.; Westermark, S.O.; Rasmuson-Lestander, Å.; Wang, X.R. Detection and quantification of Cladosporium in aerosols by real-time PCR. J. Environ. Monit. 2005, 8, 153-160.

60. Bassler, H.A.; Flood, S.J.A.; Livak, K.J.; Marmaro, J.; Knorr, R.; Batt, C.S. Use of a fluorogenic probe in a PCR-based assay for the detection of Listeria monocytogenes. Appl. Environ. Microbiol. 1995, 61, 3724-3728.

61. Dean, T.R.; Roop, B.; Betancourt, D.; Menetrez, M.Y. A simple multiplex polymerase chain reaction assay for the identification of four environmentally relevant fungal contaminants. $J$. Microbiol. Methods. 2005, 61, 9-16.

62. Livak, K.J.; Flood, S.J.; Marmaro, J.; Giusti, W.; Deetz, K. Oligonucleotides with fluorescent dyes at opposite ends provide a quenched probe system useful for detecting PCR product and nucleic acid hybridization. PCR Methods Appl. 1995, 6, 357-362.

63. Keswani, J.; Kashon, M.L.; Chen, B.T. Evaluation of interference to conventional and real-time PCR for detection and quantitation of fungi in yeast. J. Environ. Monit. 2005, 7, 311-318.

64. Morrison, E.; Kosiak, B.; Ritieni, A.; Aastveit, A.H.; Uhlig, S.; Bernhoft, A. Mycotoxin production by Fusarium avenaceum strains isolated from Norwegian grain and the cytotoxicity of rice culture extracts to porcine kidney epithelial cells. J. Agric. Food Chem. 2002, 50, 3070-3075.

65. Nitsche, A.; Steuer, N.; Schmidt, C.A.; Landt, O.; Siegert, W. Different real-time OCR formats compared for the quantiative detection of human cytomegalovirus DNA. Clin. Chem. 1999, 45, 1932-1937.

66. Schena, L.; Nigro, F.; Ippolito, A.; Gallitelli, D. Real-time quantitative PCR: A new technology to detect and study phytopathogenic and antagonistic fungi [review]. Eur. J. Plant Pathol. 2004, 110, 893-908.

67. Reischer, G.H.; Lemmens, M.; Farnleitner, A.; Adler, A.; Mach, R.L. Quantification of Fusarium graminearum in infected wheat by species specific real-time PCR applying a TaqMan probe. $J$. Microbiol. Methods. 2004, 59, 141-146.

68. Waalwijk, C.; van der Heide, R.; de Vries, I.; van der Lee, T.; Schoen, C.; Costrel-de Corainville, G.; Häuser-Hahn, I.; Kastelein, P.; Köhl, J.; Lonnet, P.; Demarquet, T.; Kema, G.H.J. Quantitative detection of Fusarium species in wheat using TaqMan. Eur. J. Plant Pathol. 2004, 110, 481-494.

69. Haugland, R.A.; Heckman, J.L.; Wymer, L.J. Evaluation of different methods for the extraction of DNA from fungal conidia by quantitative competitive PCR analysis. J. Microbiol. Methods. 1999, 37, 165-176. 
70. Zeng, Q.Y.; Westermark, S.O.; Rasmuson-Lestander, Å.; Wang, X.R. Detection and Quantificaiotion of Wallemia sebi in aerosols by real-time PCR, conventrional PCR, and cultivation. Appl. Environ. Microbiol. 2004, 70, 7295-7302.

71. Thorne, P.S.; Duchaine, C.; Douwes, J.; Eduard, W.; Górny, R.; Jacobs, R.; Reponen, T.; Schierl, R.; Szponar, B. Working group report 4: exposure assessment for biological agents. Am. J. Ind. Med. 2004, 46, 419-422.

72. Toivola, M.; Alm, S.; Reponen, T.; Kolari, S.; Nevalainen, A. Personal exposures and microenvironmental concentrations of particles and bioaerosols. J. Environ. Monit. 2002, 4, 166-174.

73. Halstensen, A.S.; Nordby, K.C.; Wouters, I.; Eduard, W. Determinants of microbial exposure in grain farming. Ann. Occup. Hyg. 2007, 51, 581-592.

74. Haugland, R.A.; Brinkman. N.; Vesper, S.J. Evaluation of rapid DNA extraction methods for the quantitative detection of fungi using real-time PCR analysis. J. Microbiol. Methods. 2002, 50, 319-323.

75. Haugland, R.A.; Varma, M.; Wymer, L.J.; Vesper, S.J. Quantitative PCR analysis of selected Aspergillus, Penicillium and Paecilomyces species. Syst. Appl. Microbiol. 2004, 27, 198-210.

76. Rintala, H.; Nevalainen, A.; Rönkä, E.; Suutari, M. PCR primers targeting the 16S rRNA gene for the specific detection of streptomyces. Mol. Cell. Probes. 2001, 15, 337-347.

77. Halstensen, A.S.; Nordby, K.C.; Klemsdal, S.S.; Elen, O.; Clasen, P.E.; Eduard, W. Toxigenic Fusarium spp as determinants of trichothecene mycotoxins in settled dust. J. Occup. Environ. Hyg. 2006, 3, 651-659.

78. Klemsdal, S.S.; Elen, O. Development of a highly sensitive nested-PCR method using a single closed tube for detection of Fusarium culmorum in cereal samples. Lett. Appl. Microbiol. 2006, 42, 544-548.

79. Tebbe, C.C.; Vahjen, W. Interference of humic acids and DNA extracted directly from soil in detection and transformation of recombinant DNA from bacteria and a yeast. Appl. Environ. Microbiol. 1993, 59, 2657-2665.

80. Tsai, Y.-L.; Olson, B.H. Detection of low numbers of bacterial cells in soils and sediments by polymerase chain reaction. Appl. Environ. Microbiol. 1992, 58, 2292-2295.

81. Wilson, W.J.; Strout, C.L.; DeSantis, T.Z.; Stilwell, J.L.; Carrano, A.V.; Andersen, G.L. Sequence-specific identification of 18 pathogenic microorganisms using microarray technology. Mol. Cell. Probes. 2002, 16, 119-127.

82. Cruz-Perez, P.; Buttner, M.P.; Stetzenbach, L.D. Detection and quantification of Aspergillus fumigatus in pure culture using polymerase chain reaction. Mol. Cell. Probes. 2001, 15, 81-88.

83. Alvarez, A.J.; Buttner, M.P.; Stetzenbach, L.D. PCR for bioaersol monitoring: sensitivity and environmental interference. Appl. Environ. Microbiol. 1995, 61, 3639-3644.

84. Bej, A.M.; Mahbubani, M.H.; Dicesare, J.L.; Atlas, R.M. Polymerase chain reaction-gene probe detection of microorganisms by using filter-concentrated samples. Appl. Environ. Microbiol. 1991, 57, 3529-3534.

85. Call, D.R.; Borucki, M.K.; Loge, F.J. Detection of bacterial pathogens in environmental samples using DNA microarrays [review]. J. Microbiol. Methods. 2003, 53, 235-243. 
86. Bavykin, S.G.; Awonsky, J.P.; Zakhariev, V.M.; Barsky, V.E.; Perov, A.N.; Mirzabekov, A.D. Portable system for microbial sample preparation and oliconucleotide microarray analysis. Appl. Environ. Microbiol. 2001, 67, 922-928.

87. Cho, J.C.; Tiedje, J.M. Bacterial species determination from DNA-DNA hybridization by using genome fragments and DNA microarrays. Appl. Environ. Microbiol. 2001, 67, 3677-3682.

88. Sachse, K.; Hotzel, H.; Slickers, P.; Ellinger, T.; Ehricht, R. DNA-microarray-based detection and identification of Chlamydia and Chlamydiophila spp. Mol. Cell. Probes. 2005, 19, 41-50.

89. Watanabe, T.; Mutara, Y.; Oka, S.; Iwahashi, H. A new approach to species determination for yeast strains: DNA microarray-based comparative genomic hybridization using a yeast DNA microarray with 6000 genes. Yeast 2004, 21, 351-365.

90. Bodrossy, L.; Sessitsch, A. Oligonucleotide microarrays in microbial diagnostics. Curr. Opin. Microbiol. 2004, 7, 245-254.

91. Kristensen, R.; Gauthier, G.; Berdal, K.G.; Hamels, S.; Remacle, J.; Holst-Jensen, A. DNA microarray to detect and identify trichothecene- and monoliformin-producing Fusarium species. $J$. Appl. Microbiol. 2006, 102, 1060-1070.

92. Lievens, B.; Claes, L.; Vanachter, A.C.R.C.; Cammue, B.P.A.; Thomma, B.P.H.J. Detecting single nucleotide polymorphisms using DNA arrays for plant pathogen diagnosis. FEMS Microbiol. Lett. 2006, 255, 129-139.

93. Franke-Whittle, I.H.; Klammer, S.H.; Insam, H. Design and application of an oligonucleotide microarray for the investigation of compost microbial communities. J. Microbiol. Methods. 2005, $62,37-56$.

94. Letowski, J.; Brousseau, R.; Masson, L. DNA microarray applicationsin environmental microbiology. Anal. Lett. 2003, 36, 3165-3184.

95. Nicolaisen, M.; Justesen, A.; Thrane, U.; Skouboe, P.; Holmstrøm, K. An oligonucleotide microarray for the identification and differentiation of trichothecene producing and non-producing Fusarium species occurring on cereal grain. J. Microbiol. Methods. 2005, 62, 57-69.

96. Sims, A.H.; Robson, G.D.; Hoyle, D.C.; Oliver, S.G.; Turner, G.; Prade, R.A.; Russell, H.H.; Dunn-Coleman, N.S.; Gent, M.E. Use of expressed sequence tag analysis and cDNA microarrays of the filamentous fungus Aspergillus nidulans. Fungal Genet. Biol. 2004, 41, 199-212.

97. Desjardins, A.E. Fusarium Mycotoxins. Chemistry, Genetics and Biology. APS Press: Minnesota, USA, 2006.

98. Niessen, L. PCR-based diagnosis and quantification of mycotoxin producing fungi. Int. J. Food Microbiol. 2007, 119, 38-46.

99. Broad Institute . Fusarium comparative database

http://www.broad.mit.edu/annotation/genome/fusarium_group/MultiHome.html;

Access date: October 31, 2008.

100. Norwegian Labour Inspection Authority Occupational limit values [In Norwegian]. 2003.

Available from: http://www.arbeidstilsynet.no/c28864/artikkel/vis.html?tid=28880;

Access date: October 31, 2008.

101. ACGIH. TLVs ${ }^{\circledR}$ and BEIs ${ }^{\circledR}$ Based on the documentation of the threshold limit values for chemical substances and physical agents and biological exposure indices. American Conference of Governmental Industrial Hygenists: Cincinnati, OH:, 2008. 
102. Eduard, W. Nordic expert group for criteria documentation of health risks from chemicals, 139. Fungal spores, 2007.

103. Sabboni, G.; Sapai, O. Determination of human exposure to aflatoxins. In Mycotoxins in Agriculture and Food Safety; Sinha, K.K., Bhatnagar, K., Eds.; Marcel Dekker: New York, 1994; pp. 183-226.

104. Campbell, T.L.; Caedo, J.P.; Bullatto, J.J.; Salamet, L.; Engel, R.W. Aflatoxin $M_{1}$ in human urine. Nature 1970, 227, 403-404.

105. Hooper, D.; Bolton, V.; Gray, M.R. Fungal mycotoxins can be detected in tissue and body fluids of patients with a history of exposure to toxin producing molds, 2006. Available from: http://www.realtimelab.com/documents/MycotoxinPosterMay162007.pdf; access date: November 24, 2008.

(C) 2008 by the authors; licensee Molecular Diversity Preservation International, Basel, Switzerland. This article is an open-access article distributed under the terms and conditions of the Creative Commons Attribution license (http://creativecommons.org/licenses/by/3.0/). 